\title{
FUNCTIONAL RESPONSE OF Nabis punctipennis Blanchard to Acyrthosiphon pisum Harris IN THE LABORATORY
}

\author{
Verónica Campos ${ }^{1}$, y Jaime E. Araya ${ }^{2 *}$ \\ ${ }^{1}$ Purdue University, W. Lafayette, Indiana 47905, USA. camposvero@gmail.com \\ 2 Universidad de Chile, Facultad de Agronomía, Casilla 1004, Santiago, Chile. \\ * Corresponding author E-mail: jaimearaya@yahoo.com
}

\section{RESUMEN}

Se analizó la conducta de depredación de hembras adultas de Nabis punctipennis Blanchard (Nabidae) hacia Acyrthosiphon pisum Harris (Aphididae) en laboratorio para determinar su respuesta funcional y su potencial como agente de control biológico de este áfido. Ambos hemípteros son comunes en alfalfa, Medicago sativa L., en Chile. Las hembras de N. punctipennis presentaron una respuesta funcional tipo II, con un tiempo de manipulación de $2,757 \pm 0,1181 \mathrm{~h}_{\text {presa }}{ }^{-1} \mathrm{y}$ una tasa de búsqueda de $0,353 \pm 0,3214 \mathrm{~h}^{-1}$.

Palabras clave: pulgón de la alfalfa, respuesta funcional, control natural, nábido de alas punteadas.

\section{ABSTRACT}

This study analyzed the predatory behavior of adult females of Nabis punctipennis Blanchard (Nabidae) towards Acyrthosiphon pisum Harris (Aphididae) in the laboratory in order to determine its functional response and potential as a biological control agent of this aphid. Both hemipterans are common in alfalfa, Medicago sativa $\mathrm{L}$., in Chile. The females of N. punctipennis presented a type II functional response, with a handling time of $2.757 \pm 0.1181 \mathrm{~h}$ prey-1 and a searching rate of 0.353 $\pm 0.3214 \mathrm{~h}^{-1}$.

Key words: Alfalfa aphid, functional response, natural control, punctured-winged nabid.

\section{INTRODUCTION}

Alfalfa (Medicago sativa L.) favors the development of many invertebrates in Chile (Gerding and Devotto, 2000), such as Acyrthosiphon pisum (Harris) (Hem. Aphididae). This insect pest can reach densities that reduce forage and seed production (Cardinale et al., 2003; Rojas, 2005). Although Nabis punctipennis Blanchard (Hem. Nabidae) have been recognized as a generalist predator (Rebolledo et al., 2005; Romero et al. 2007), there is little research on its potential as a predator for Acyrthosiphon pisum.

To determine the way in which predation varies with prey density, the predator-prey relationship should be understood (van Leeuwen et al., 2007), as both the capacity of finding a prey as the population growth of a predator depend of the density of the first ( $\mathrm{O}^{\prime} \mathrm{Neill}$ and Wiedenmann, 1987). The numerical response of a predator is the change in its reproductive rate in response to changes in prey density, while the functional response refers to the change in the consumption rate of an individual predator in response to changes in prey density in a time unit, and is expressed as a function of prey density. On the other hand, the functional response is important to provide information of the potential efficiency of a predator as a biological control agent (Omkar and Pervez, 2004; van Leeuwen et al., 2007; Cabral et al., 2009). There are three functional responses: Type I, typical of aquatic invertebrates, increases linearly until reaching a plateau, and the line slope represents the searching rate of the predator; Type II, in predator and parasitoid arthropods, increases at a decreasing rate due to

Received: 13 July 2016. Accepted: 26 January 2017. 
the effect of the handling time of the prey, and the searching time decreases; and Type III, used first for predator vertebrates and then to describe the behavior of some predators and parasitoid arthropods, it is sigmoid and has an accelerated increase in consumption as a function of prey density, until handling time limits it (Berryman, 1999).

Hollings's disk equation (Skalski and Gilliam, 2001) is commonly used to characterize the response of generalist predators to an increase in prey density (Ma et al., 2005; Pakyari et al., 2009), assuming that predators search for prey at random, with a fixed encounter probability (Fernández and Corley, 2004). Using the disk equation, Ma et al. (2005) found that the consumption of Plutella xylostella (L.) (Lep. Plutellidae) larvae by adult Nabis kinbergii Reuter described a type II functional response, and Siddique and Chapman (1987) found that functional response type III described the changes in predation of $A$. pisum by $5^{\text {th }}$ instar nymphs of $N$. kinbergii.

A good understanding of the predator-prey relationship allows developing biological control programs successfully (Flores et al., 2010). Studies, like the one conducted by Costamagna and Landis (2007), are important as they allow predicting the contribution of natural enemies to control pests so that producers can trust these organisms and include them in control strategies (Zalucki et al., 2009).

Due to the abundance of $N$. punctipennis in alfalfa fields in Chile (Rebolledo et al., 2005), it is important to study its behavior as a natural agent in conservative biological control programs that minimize the risks associated with the introduction of species (i.e., classical biological control) (Lavandero et al., 2006). It is important to maintain the control agents present in the crop, and enhance their abundance and activity because the increase in predator density generates a greater control of pests, as described by Chang and Snyder (2004), Ostman (2004), and Cardinale et al. (2003).

The predatory behavior of adult females of $N$. punctipennis towards A. pisum was studied in the laboratory to determine its functional response and potential as biological control agent of this aphid.

\section{MATERIALS AND METHODS}

Rearing N. punctipennis and A. pisum. Adults $(\sim 50)$ of N. punctipennis were collected with an entomology net at the beginning of spring (October) in alfalfa untreated with insecticides in El Noviciado $\left(33^{\circ} 26^{\prime} \mathrm{S}, 70^{\circ} 43^{\prime} \mathrm{W}\right)$, Pudahuel commune, Metropolitan Region, Chile. These predators were fasted $48 \mathrm{~h}$ in individual Petri dishes lined with slightly humid filter paper to avoid natural enemies. They were then set free to obtain eggs in $50 \times 50 \times 50 \mathrm{~cm}$ cotton mesh covered cages with 'Blanca dulce' Vicia faba L. plants infested with A. pisum obtained with the net in the same crop. Faba beans were used because they are easy-tohandle host plants to rear the aphids. The stems were revised after $7 \mathrm{~d}$; those with eggs inserted were cut into pieces and placed in $12 \times 6.05 \times 17$ $\mathrm{cm}$ transparent cages with humidified cotton, and kept at $24^{\circ} \mathrm{C}$ and a $14: 10 \mathrm{~h}$ L:D regime. Nymph emergence was recorded daily; nymphs were set individually in Petri dishes, maintained at $24^{\circ} \mathrm{C}$ for $2 \mathrm{~d}$ and fed with aphids. Then, they were set free on $V$. faba plants with $A$. pisum in $50 \times 50 \times 50$ $\mathrm{cm}$ cotton mesh cages of at $22-28^{\circ} \mathrm{C}$ in the laboratory, reaching adulthood in $\sim 20 \mathrm{~d}$.

Experimental arena (EA). The EA was a 350 $\mathrm{mL}$ transparent plastic cage, with a $2 \mathrm{~cm}$ diameter hole on the base to introduce a $\sim 12 \mathrm{~cm}$ stem piece of $V$. faba var. 'Blanca agua dulce'. The hole around the stem was sealed with high density polyurethane foam, and the top of the EA was covered with cotton cloth. To keep the stem turgid, the EA was placed on a $200-\mathrm{mL}$ plastic transparent container with water.

Only 10-15 d-old adult females of N. punctipennis from the rearing cages were used in the experiment. The selected nabids were placed individually in Petri dishes with no food, so as to guarantee similar stomach content. They were only provided with a piece of humidified cotton at $24^{\circ} \mathrm{C}$ and a 14:10 L:D photoperiod for $24 \mathrm{~h}$. Subsequently, they were used in the experiment to determine the functional response. For this, the nabids were placed individually in the EA and exposed to five different densities of A. pisum of similar size: 3, 9, 18,36 , and 54 per EA. In addition, a control treatment, which consisted of an EA with 18 aphids and no predator was included to determine natural mortality. The EAs were maintained at $24^{\circ} \mathrm{C}$ and a 14:10 L:D regime. After $24 \mathrm{~h}$, the predators were discarded and the aphids remaining in each treatment were counted.

Experiment design and statistical analysis. The experiment was conducted using a complete randomized block design with 6 treatments and 10 replications.

To compare the numbers of preys killed at each density, the results were analyzed with ANOVA at $5 \%$ significance, using MINITAB 13.32 (Minitab Inc., 2000) statistic software. Tukey's test was applied to separate means. To determine the functional response type (I, II, or III), a logistic regression was obtained with the Eviews 6 (QMS, 
2007) statistic software, using the following cubical equation:

$$
\begin{gathered}
N a / N t=\exp \left(P_{0}+P_{1} N t+P_{2} N t^{2}+P_{3} N t^{3}\right) / 1+\exp \left(P_{0}\right. \\
+P_{1} N t+P_{2} N t^{2}+P_{3} N t^{3}
\end{gathered}
$$

where $\mathrm{Na}=$ number of preys consumed by the predator, $N t=$ initial prey density, and $P_{0^{\prime}} P_{1^{\prime}} P_{2^{\prime}}$ $P_{3}=$ constant parameter, and linear, quadratic, and cubical parameters, respectively.

As the parameter is related to the slope of the curve generated between the proportion of preys consumed $(\mathrm{Na} / \mathrm{N} t)$ and the number of preys offered to the predator $(\mathrm{Nt})$, and also considering that the slope allows discriminating between the types of functional response at a low prey density (Fernández and Corley, 2004), this would be type I if parameter $P_{1}=0$, type II if $P_{1}$ is negative and significant, and type III if $P_{1}$ is positive and significant (Lee and Kang, 2004).

To determine handling time and searching rate, a curvilinear regression by minimal squares was done with the Eviews 6 (QMS, 2007) statisti- cal software, fitted to the disc equation:

$$
N a=T * a * N t / 1+(a * h * N t)
$$

where $\mathrm{Na}=$ number of preys consumed by the predator, $N t=$ initial prey density, $T=$ experimental period $(24 \mathrm{~h}), a=$ searching rate, and $h=$ handling rate.

\section{RESULTS AND DISCUSSION}

Functional response. The number of $A$. pisum preys consumed by adult females of $N$. punctipennis increased significantly when the density of aphids per EA increased from 3 to 9 and from 9 to 18 (T1, T2, and T3). However, there was no significant increase in aphid consumption when density went from 18 to 36 , and from 36 to 54 aphids per EA. The mean daily consumption was $7.7 \pm 0.949$ aphids (Table 1 ). There was no natural mortality of the 18 aphids in the EA corresponding to the control treatment.

Predator satiation of adult females of N. punc-

Table 1. Mean consumption of A. pisum per female adult of $N$. punctipennis at several aphid densities per EA at $24^{\circ} \mathrm{C}$ for $24 \mathrm{~h}$.

\begin{tabular}{ccc}
\hline Treatments & Densities of A. pisum per EA & Mean consumption \pm SD \\
\hline 1 & 3 & $2.5(0.527) \mathrm{c}$ \\
2 & 9 & $5.0(0.810) \mathrm{b}$ \\
3 & 18 & $7.1(1.370) \mathrm{a}$ \\
4 & 36 & $7.5(0.850) \mathrm{a}$ \\
5 & 54 & $7.7(0.949) \mathrm{a}$ \\
\hline
\end{tabular}

EA: Experimental arena.

Means with different letters are significantly different, according to a Tukey test $(\varrho<0.05)$.

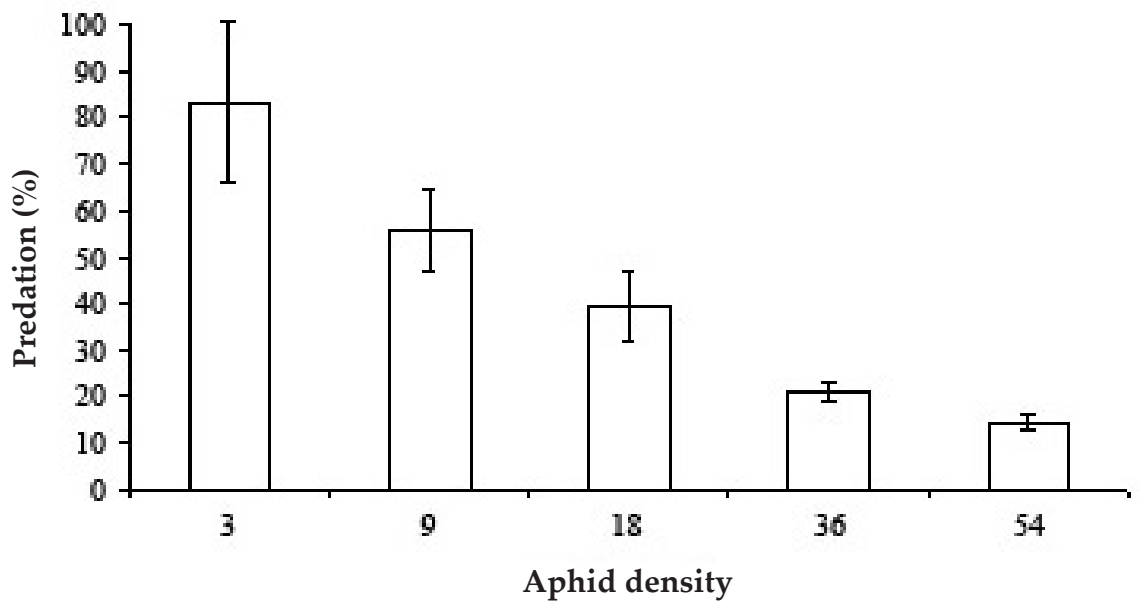

Fig. 1. Predation (\%) of $A$. pisum by female adults of $N$. puntipennis in the laboratory. The columns indicate the averages of aphids consumed, with their corresponding standard deviation. 
tipennis under the conditions of the bioassay would be 18 aphids per EA. Consumption did not increase at higher densities. This indicates that $N$. punctipennis would be more efficacious controlling $A$. pisum at smaller densities since predation rate was higher at lower densities (Fig. 1). This seems to be a key point because Ostman (2004) states that aphid control should occur early in the season during pest establishment, and so predators need to be already in the field when aphids develop. Therefore, it is important to note that presence of $N$. punctipennis can be found throughout all growth stages of alfalfa (Romero et al., 2007). The saturation asymptote of N. punctipennis occurred more quickly compared to other generalist predators, like some coccinellids (Sarmento et al., 2007; Cabral et al., 2009), which indicates that this nabid is not too voracious. However, its abundance in alfalfa seems to contribute to aphid control in terms of consumption of the total population of nabids, more than consumption per capita.

The low prey consumption by nabids can be associated with their small size (5-6 mm), or their small energy requirements. They are expected to complete their cycle with a small predation level, and remain in the crop regardless of fluctuations in the population of A. pisum.

The highest predation rate was observed at a lower density, and corresponded to 3 aphids per EA. The number of aphids captured by the nabids averaged $80 \%$, demonstrating its efficacy in capturing prey at low densities when aphids are well-dispersed. On the contrary, aphids tend to cluster on leaf undersides at greater densities. This type of behavior is important when selecting potential natural enemies, because it provides information on the predator's capacity to find its prey (Cédola and Botto, 1996).

Adult females of $N$. punctipennis presented a typical type II functional response since the estimated value of parameter $P_{1}$ was negative and significant (Table 2). As expected, predation rate decreased when prey density increased (Fig. 1).

A type III functional response is ideal for biological control because consumption rate is higher when increasing prey density (Fernández and
Corley, 2004; van Leeuwen et al., 2007). However, most natural enemy arthropods have type II responses, as is the case of $N$. punctipennis, that exhibited a lower consumption rate at higher densities (Fig. 2).

The functional response of a predator may vary, as described by Sarmento et al. (2007). These authors evaluated the response of Eriopis connexa Germar (Col. Coccinellidae) to Macrosiphum euphorbiae (Hem. Aphididae) and found a type III response, which changed to type II when the prey was changed to Tetranychus evansi Baker \& Pritchard (Acari Tetranychidae). This was attributed to learning (Speight et al., 1999) that could develop the coccinellid initially when attacking $M$. euphorbiae. The predator had a type II response for T. evansi, associated with its lack of escaping mechanisms.

Handling time to pursue, dominate, consume, and digest the prey, includes the preparation of the predator for the next search. As handling reduces the time spent to search the prey, maximum consumption is expressed when the plateau is reached in a response type II. This is equal to the quotient between the experiment time $(T)$, herein $24 \mathrm{~h}$, and handling time $(h ; 2.676 \mathrm{~h} /$ prey in Table 3), while searching time is negligible (Begon et al., 1996; Fernández and Corley, 2004).

The handling time estimated (Table 3), which is relatively longer than in other predators (Sarmento et al., 2007; Cabral et al., 2009), may be explained by the behavior of N. punctipennis. This species catches its prey approaching it from behind to avoid detection; when it is close enough, it jumps on and immobilizes its prey with the front legs to insert the stylet and feed. This activity takes some time, as observed in this study, and also by Romero et al. (2007).

When feeding from A. pisum, the nabid N. kinbergii pierces the body of the aphid and leaves it alone, and only holds the prey when this stops resisting (Siddique, 1985). Thus, considering both feeding behaviors, it is not strange to find nabids with long handling times.

Handling time can be measured, but searching rate $(a)$ is a function of the number of contacts between predator and prey. In fact, searching time depends on the maximum distance at which

Table 2. Parameters estimated of the logistical regression to determine the functional response type of female adults of N. punctipennis against A. pisum in the laboratory.

\begin{tabular}{ccc}
\hline Parameters & Estimated values $( \pm$ SD) & Q values \\
\hline$P_{0}$ & $0.974650(0.1574)^{*}$ & 0.0000 \\
$P_{1}$ & $-0.091401(0.0249)^{*}$ & 0.0007 \\
$P_{2}$ & $0.000768(0.0010)$ & 0.4524 \\
$P_{3}$ & $-4.91 \times 10^{-7}\left(1.14 \times 10^{-5}\right)$ & 0.9659 \\
\hline
\end{tabular}

* Statistically significant with $\alpha=0.01$. 
Table 3. Searching rate and handling time ( \pm SD) estimated with the disk and attack equations of $A$. pisum by female adults of $N$. punctipennis in the laboratory.

\section{Estimated with the disk equation}

\begin{tabular}{cc}
\hline Searching rate $\left(\right.$ hours $\left.^{-1}\right)$ & Handling time (hours/prey) \\
\hline $0.055(0.0067)$ & $2.676(0.1097)$ \\
\hline \multicolumn{2}{c}{ Estimated with the attack equation } \\
$0.353(0.3214)$ & $2.757(0.1181)$ \\
\hline
\end{tabular}
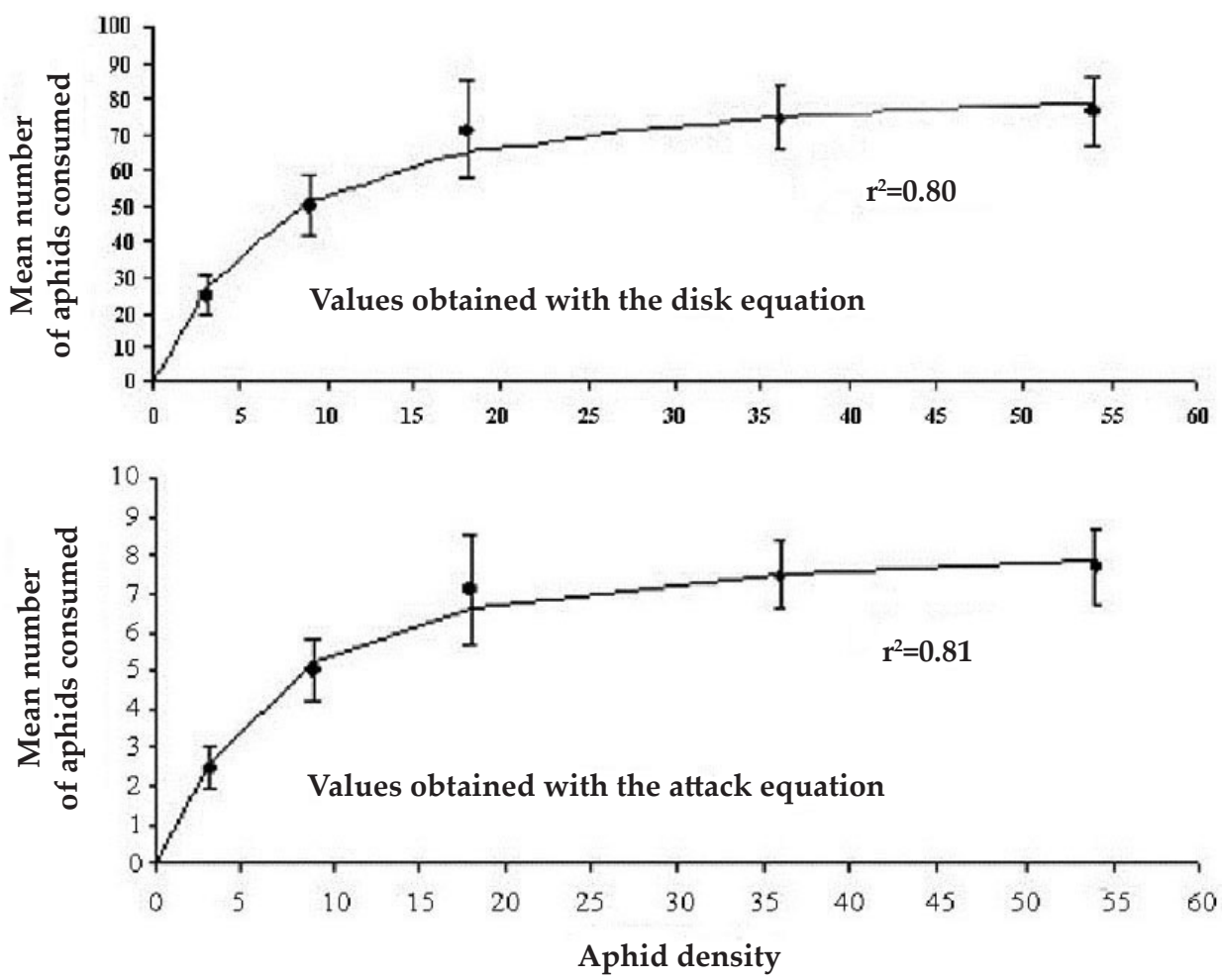

Fig. 2. Functional response of female adults of N. punctipennis against A. pisum in the laboratory, at $24^{\circ} \mathrm{C}$ for $24 \mathrm{~h}$. The curves indicate the values expected $( \pm \mathrm{SD}$ ) with the disk (above) and attack (below) equations.

a predator can begin attacking a prey, the quickness of movement exhibited by the predator and prey, and the amount of successful attacks (Begon et al., 1996).

The searching rate was estimated with the disk equation and reached a value of $0.055 \mathrm{~h}^{-1}$ (Table 3). This seems real even though it has been described that large handling times lead to low searching rates (Smith and Smith, 2001) and, consequently, the estimated value may seem too small for the total consumption. If this value is right, 1.32 attacks would occur in $24 \mathrm{~h}$, which is nonsense if $N$. punctipennis presented a maximum predation of $7.7 \pm 0.949$ aphids in the same peri- od (Table 3). This result can be explained by the fact that the disc equation assumes that the predator searches at random for preys, which are also distributed at random, with a constant handling time, and a fixed encounter probability between predator and prey, without considering the effect of decreasing the number of prey. Therefore, it is more adequate in bioassays where preys consumed are replaced, and the density is kept constant, or in large-size EA where the effect of consumption is negligible (Fernández and Corley, 2004). The limitations stated have prompted models like the attack equation (Berryman, 1999).

This model assumes that the predator search- 
es for its prey at random, while searching rate and handling time are estimated similarly to those observed in bioassays where the preys are not replenished and a variation in density occurs (Lee and Kang, 2004).

The handling time estimated with the attack equation was similar to that obtained with the disc equation (Table 3). However, the searching rate was higher, which explains what was observed during the functional response bioassays when using the attack equation; a value of 0.353 $\mathrm{h}^{-1}$ was obtained, with a maximum consumption of 8.472 prey during the $24 \mathrm{~h}$ test, which is a reasonable level if maximum consumption was $7.7 \pm$ 0.949 prey (Table 3 ).

A type II functional response was obtained from the results expected with the attack equation.

When comparing the curves in Fig. 2, it can be observed that the adjustment obtained was similar in both the disk and attack equations. However, the adjustment was a little higher in the attack equation, when its greater coefficient of determination was used as a parameter. This indicates that the attack equation better explains the variations in consumption of $A$ pisum by $N$. punctipennis in relation with prey density.

Type II functional responses, like those found here in for N. punctipennis, have been observed by other nabids in the presence of aphids. A study conducted by Siddique and Chapman (1987) also found this kind of curve when evaluating the functional response of adult females of N. kinbergii to A. pisum. The preys consumed were replenished during that study and the results indicated a searching rate and handling time of 0.312 \pm 0.171 , and $2.618 \pm 0.463 \mathrm{~h}$, respectively, using the disc equation. When comparing the handling time and attack rate of $N$. kinbergii determined with the disk equation in their study and the values of N. punctipennis that we obtained with the attack equation, it can be stated that the results were quite similar because values were slightly higher in the case of N. punctipennis for both parameters (Table 3 ).

Siddique and Chapman (1987) used a much larger EA than ours for N. punctipennis. Greater EAs generate greater searching rates (Logan et al., 2009), and a much higher parameter should be expected in N. kinbergii. However, there is a slight difference between both nabids, suggesting that $N$. kinbergii is more efficient towards the same prey. This may be due to the size difference, as $N$. punctipennis is 5-6 mm long (Artigas, 1994) and $N$. kinbergii $8 \mathrm{~mm}$ (Wade et al., 2005). According to Hassell et al. (1976), larger species present greater searching efficiency. The distribution of aphids should also be considered, as they generally concentrate on a plant level (Rojas, 2005) and, conse- quently, nabids do not need to search all over the EA to find their prey.

The disk and attack equations use three components that occur in all predation events, and estimate the functional response of a predator to a prey, such as attack rate, handling time and experimental time both species are exposed to. However, other unconsidered factors could affect the functional response, for example: how hungry the predator is, age (Siddique, 1985), learning (Morales et al., 2001), size of the predator and prey, prey defense strategies (Villagra et al., 2002; Sarmento et al., 2007), and its distribution (Pitt and Ritchie, 2002), as well as environment factors like temperature (Gitonga et al., 2002; Pakyari et al., 2009). To prevent these factors from affecting the functional response of the nabid, the bioassays were conducted only with 10-15 d-old adult females, which were kept with no food for $24 \mathrm{~h}$ to level their gut content. The preys were selected considering a relatively homogeneous size, and the tests were carried out at a stable temperature $\left(24^{\circ} \mathrm{C}\right)$.

This laboratory study is the first evaluation of $N$. punctipennis as a biological control agent for A. pisum. Some authors have indicated that the functional response in the laboratory could reflect what happens in the field, particularly under high prey infestations (Lee and Kang, 2004; Omkar and Pervez, 2004). Each A. pisum female produces 50-100 nymphs in 7-10 $\mathrm{d}$, and nymphs complete their cycle in only $12 \mathrm{~d}$ (Artigas, 1994) to become reproducing adults. Therefore, their density in the field increases fast, forming colonies on the tender structures (Rojas, 2005), as observed in alfalfa when collecting the predator. Then, the functional response obtained herein could predict the predation conduct of $N$. punctipennis on A. pisum in the field.

Small EAs may generate searching efficiency values that may vary considerably from those observed in the field, which represents a limitation for the study of functional responses under laboratory conditions (Murdoch, 1983, Symondson et al., 2002). In addition, the characteristics of the plant affect predation, and its structure affects searching efficiency (Carter et al., 1984) and handling time (Symondson et al., 2002). Prey density varies greatly in crop systems due to interactions between predators related to predator density, interference, and cannibalism (Symondson et al., 2002). Romero et al. (2007) observed cannibalism by neonate nymphs I of $N$. punctipennis emerging from the egg. This behavior decreases the number of predators, but it may also cause an increase in the per capita functional response (Symondson et al., 2002), which would not necessarily reduce consumption. Deficiencies when estimating the functional response in the laboratory could be 
solved with field studies. However, obtaining an adequate number of predation events requires a lot of time, and it does not seem feasible for moving predators that feed on ungrouped prey (Schenk and Bacher, 2002).

When comparing $N$. punctipennis to generalist predators commonly found in alfalfa, prey consumption is greater in the coccinellids (Grez et al., 2007; Sarmento et al., 2007), considering predation by the three most abundant species, $E$. connexa, Adalia bipunctata (L.), and Hippodamia variegata (Goeze) (Col. Coccinellidae) (Zaviezo et al., 2004, 2006). However, their presence in alfalfa is very dynamic (Zaviezo et al., 2004; Rebolledo et al., 2009). Although the nabid per capita consumption is not high, it is the most common predator in alfalfa in the Metropolitan Region throughout crop growth, reaching maximum density in the spring, from November through December (Romero et al., 2007). This is important for aphid control since predation of aphids early in the season is a key issue to control them (Ostman et al., 2003; Ostman, 2004). Aphid population in alfalfa in the Central Valley of Chile is higher during the spring (Grez et al., 2010), as we could also confirm when collecting the material. Thus, it seems that $N$. punctipennis would be controlling the aphids in a key period. Besides, N. punctipennis can feed from the first nymph stage on even larger prey, as observed herein and by Romero et al. (2007). Finally, adults have a $59.9 \pm 25.34 \mathrm{~d}$ lifespan (Rebolledo et al., 2005), and females lay an average of 200 eggs (Romero et al., 2007). On this respect, Costamagna and Landis (2007) evaluated the consumption of Aphis glycines Matsumura (Hem. Aphididae) by generalist predators in soybean crops and indicated that when predators are more stable in a crop, such as nabids in alfalfa, they control a pest better as a result of its abundance more than due to per capita consumption.

In general, N. punctipennis may contribute to control A. pisum mainly because it is a stable resource in alfalfa; it is present in the key periods for aphid control; and its abundance makes up for its low per capita consumption.

The simplified environment a predator is exposed to in the laboratory does not always allow predicting its efficiency as a biological control agent in the field (Lester and Harmsen, 2002). Therefore, studies in the laboratory can be complemented with studies under conditions that are more similar to those in the field, including all moving stages and sexes of N. puntipennis.

If $N$. punctipennis turns to be an efficient biological control agent, some strategies should be considered to protect nabids, for example, using preferably insecticides like spinosad, which affects it relatively less than other chemicals (Rome- ro et al., 2009). In addition, alfalfa could be grown in smaller patches, as for Ostman et al. (2003), aphid density relates inversely with the margins of the crop.

\section{CONCLUSIONS}

The functional response of adult females of $N$. punctipennis to A. pisum in the laboratory was type II, and it was characterized by a high efficiency of consumption at low prey density.

The methodology used was adequate, as it allowed simulating the predation behavior of $A$. pisum by adult females of $N$. punctipennis in the laboratory. However, the estimation of handling time and searching rate of A. pisum by N. punctipennis adult females with the disc equation did not yield satisfactory results. Because of this, the attack equation model was also used, obtaining results that explained in a better way the observations made during this study.

Further studies on the functional response for all the prey stages of N. punctipennis should be conducted as they all consume A. pisum.

\section{LITERATURE CITED}

Artigas, J. 1994. Entomología económica: insectos de interés agrícola, forestal, médico y veterinario (nativos, introducidos y susceptibles de ser introducidos). 943 p. Ed. Univ. de Concepción, Concepción, Chile.

Begon, M., M. Mortimer, and D. Thompson. 1996. Population ecology, a unified study of animals and plants. 247 p. $3^{\text {rd }}$ ed. Blackwell Science, Liverpool, UK.

Berryman, A. 1999. Principles of population dynamics and their application. Stanley Thornes, Cheltenham, USA.

Cabral S., A. Soares, and P. Garcia. 2009. Predation by Coccinella undecimpunctata L. (Coleoptera: Coccinellidae) on Myzus persicae Sulzer (Homoptera: Aphididae): Effect of prey density. Biol. Control 50:25-29.

Cardinale, B., C. Harvey, K. Gross, and A. Ives. 2003. Biodiversity and biocontrol: emergent impacts of a multi-enemy assemblage on pest suppression and crop yield in an agroecosystem. Ecology Letters 6:857-865.

Carter M, D. Surtherland, and A. Dixon. 1984. Plant structure and the searching efficiency of coccinellid larvae. Oecologia 63:394-397.

Cédola, C., y E. Botto. 1996. Evaluación de la respuesta funcional de Amblyseius idaeus Moraes \& McMurtry, 1983 y Phytoseiulus macropilis (Banks, 1905) (Acarina: Phytoseiidae) en condiciones de laboratorio. Rev. Chilena de Entomología 23:15-18. 
Chang, G., and W. Snyder. 2004. The relationship between predator density, community composition, and field predation of Colorado potato beetle eggs. Biol. Control 31:453-461.

Costamagna, A., and D. Landis. 2007. Quantifying predation on soybean aphid through direct field observations. Biol. Control 42:16-24.

Fernández, V., y J. Corley. 2004. La respuesta funcional: una revisión y guía experimental. Ecología Austral 14:83-93.

Flores, A., S. Rodríguez, M.G. Ramos, y F. Payán. 2010. Estudio de Harmonia axirydis Pallas (Coleoptera: Cocinellidae) como bioagente de control de Aphis gossypii Glover (Hemiptera: Aphididae). Interciencia 35:506-509.

Gerding, M., y L. Devotto. 2000. Plagas de la alfalfa. p. 109-125. En Soto, P. (ed.) Alfalfa en la zona centro sur de Chile. INIA, Chillán, Chile

Gitonga, L., W.A. Overholt, B. Lohr, J.K. Magambo, and J.M. Mueke. 2002. Functional response of Orius albidipennis (Hemiptera: Anthocoridae) to Megalurothrips sjostedti (Thysanoptera: Thripidae). Biol. Control 24:1-6.

Grez, A., P. Rivera, and T. Zaviezo. 2007. Foliar and ground-foraging predators of aphids associated with alfalfa crops in Chile: are they good or bad partners? Biocontrol Sci. \& Technol. 17:1071-1077.

Grez, A., C. Torres, T. Zaviezo, B. Lavandero, and M. Ramírez. 2010. Migration of coccinellids to alfalfa fields with varying adjacent vegetation in Central Chile. Ciencia e Invest. Agraria 37:111-121.

Grez, A., y T. Zaviezo. 2002. Efectos inmediatos de la fragmentación del hábitat sobre la abundancia de insectos en alfalfa. Ciencia e Invest. Agraria 29:29-34.

Hassell, M., J. Lawton, and R. May. 1976. Patterns of dynamical behaviour in single species populations. J. Animal Ecol. 45:471-486.

Lavandero, B., C. Muñoz, y W. Barros. 2006. El talón de Aquiles del control biológico: una visión para su éxito. Agro-Ciencia 22:111123.

Lee, J., and T. Kang. 2004. Functional response of Harmonia axyridis (Pallas) (Coleoptera: Coccinellidae) to Aphis gossypii Glover (Hemiptera: Aphididae). Biol. Control 31:306-310.

Lester, P., and R. Harmsen. 2002. Functional and numerical responses do not always indicate the most effective predator for biological control: an analysis of two predators in a two-prey system. J. Appl. Ecol. 39:455-468.

Logan, J.D., G. Ledder, and W. Wolesensky. 2009. Type II functional response for continuous, physiologically structured models. J. Theoretical Biol. 259:373-381.
Ma, J., Y. Li, M. Keller, and S. Ren. 2005. Functional response and predation of Nabis kinbergii (Hem.: Nabidae) to Plutella xylostella (Lep.: Plutellidae). Insect Sci. 12:281-286.

Minitab Inc. 2000. Minitab version 13.23. State College, Pennsylvania, USA.

Morales, J., J. Gallardo, C. Vásquez, y Y. Ríos. 2001. Respuesta funcional de Telenomus remus (Hymenoptera: Scelionidae) a los huevos de Spodoptera frugiperda (Lepidoptera: Noctuidae). Bioagro 13:49-55.

Murdoch, W. 1983. The functional response of predators. J. Appl. Ecol. 10:335-342.

Omkar, P., and A. Pervez. 2004. Functional and numerical responses of Propylea dissecta (Col., Coccinellidae). J. Appl. Ent. 128:140-146.

O'Neill, R., and R. Wiedenmann. 1987. Adaptations of arthropod predators to agricultural systems. Florida Ent. 70:40-48.

Ostman, O. 2004. The relative effects of natural enemy abundance and alternative prey abundance on aphid predation rates. Biol. Control 30:281-287.

Ostman, O., B. Ekbom, and J. Bengtsson. 2003. Yield increase attributable to aphid predation by ground-living polyphagous natural enemies in spring barley in Sweden. Ecol. Economics 45:149-158.

Pakyari, H., Y. Fathipour, M. Rezapanah, and K. Kamali. 2009. Temperature-dependent functional response of Scolothrips longicornis (Thysanoptera: Thripidae) preying on Tetranychus urticae. J. Asia-Pacific Ent. 12:2326.

Pitt, W., and M. Ritchie. 2002. Influence of prey distribution on the functional responses of lizards. Oikos 96:157-163.

QMS. 2007. Eviews 6. User's guides I and II, Irvine. Quantitative Micro Software (QMS), California, USA.

Rebolledo, R., J. Sheriff, L. Parra, and A. Aguilera. 2009. Life, seasonal cycles, and population fluctuation of Hippodamia variegata (Goeze) (Coleoptera: Coccinellidae), in the central plain of La Araucanía Region, Chile. Chilean J. Agric. Res. 6:292-298.

Rebolledo, R., R. Villegas, C. Klein, y A. Aguilera. 2005. Fluctuación poblacional y capacidad depredadora de Nabis punctipennis Blanchard (Hemiptera: Nabidae). Agricultura Técnica (Chile) 65:442-446.

Rojas, S. 2005. Control biológico de plagas en Chile, historia y avances. $123 \mathrm{p}$. Instituto de Investigaciones Agropecuarias (INIA), Santiago, Chile. 
Romero, C., J. Araya, M.A. Guerrero, y T. Curkovic. 2009. Efecto de carbaril, metamidofos, lambda cihalotrina y spinosad sobre ninfas de Nabis punctipennis Blanchard (Hemiptera: Nabidae). Bol. San. Veg., Plagas 35:371-376.

Romero, C., J. Araya, M.A. Guerrero, T. Curkovic, y E. Viñuela. 2007. Biología del depredador generalista Nabis punctipennis Blanchard (Hemiptera: Nabidae). Phytoma (España) 191:36-44.

Sarmento, R., A. Pallini, M. Venzon, F. Fonseca de Souza, J. Molina-Rugama, and C. Lima de Oliveira. 2007. Functional response of the predator Eriopis connexa (Coleoptera: Coccinellidae) to different prey types. Brazilian Arch. of Biol. and Technol. 50:121-126.

Schenk, D., and S. Bacher. 2002. Functional response of a generalist insect predator to one of its prey species in the field. J. Animal Ecol. 71:524-531.

Siddique, M.A. 1985. Biology and predation of Pacific damsel bug, Nabis kinbergii Reuter, (Hemiptera: Nabidae). Doctoral thesis. University of Canterbury, Lincoln College, Christchurch, New Zealand.

Siddique, M.A., and R. Chapman. 1987. Functional response of pacific damsel bug, Nabis kinbergii (Hemiptera: Nabidae). Entomophaga 32:303-309.

Skalski, G., and J. Gilliam. 2001. Functional responses with interference: viable alternatives to the Holling type II model. Ecology 81:3083-3092.
Smith, R., y T. Smith. 2001. Ecología. 605 p. Pearson Educación, Madrid, España.

Speight, M., M. Hunter, and A. Watt. 1999. Ecology of insects: concepts and applications. 360 p. Blackwell Science, Oxford, UK.

Symondson, W., K. Sunderland, and M. Greenstone. 2002. Can generalist predators be effective biocontrol agents? Ann. Rev. Ent. 47:561-594.

van Leeuwen, E., V. Jansen, and P. Bright. 2007. How population dynamics shape the functional response in a one-predator-two-prey system. Ecology 88:1571-1581.

Villagra, C., C. Ramírez, and H. Niemeyer. 2002. Anti predator responses of aphids to parasitoids change as a function of aphid physiological state. Animal Behaviour 64:677-683.

Wade, M., M. Zalucki, and B. Franzmann. 2005. Influence of observer presence on Pacific damsel bug behaviour: Who is watching whom? J. Insect Behaviour 18:651-667.

Zalucki, M., D. Adamson, and M. Furlong. 2009. The future of IPM: whither or wither? Australian J. Ent. 48:85-96.

Zaviezo, T., A. Grez, y D. Donoso. 2004. Dinámica temporal de coleópteros asociados a alfalfa. Ciencia e Investigación Agraria 31:29-38.

Zaviezo, T., A. Grez, C. Estades, and A. Pérez. 2006. Effects of habitat loss, habitat fragmentation and isolation on the density, species richness and distribution of ladybeetles in manipulated alfalfa landscapes. Ecol. Ent. 31:646-656. 